\title{
THE NURSING CONTRIBUTORS TO HEALTH SERVICES OF THE BLACK STATES
}

O. H. Muller B.A. (S.A.) B. Cur., Chief Nursing Officer, Department of Health J. J. M. Smit B. Cur. (I. et A.), Organiser of Nursing Services (General Education) Department of Health

\section{OPSOMMING}

Die Swart bevolking van Suid-Afrika bestaan uit verskillende etniese groepe waarvan sewe groepe tuislande besit. Transkei en Bophuthatswana, vorige tuislande, is reeds onafhanklik vanaf 1976 en 1977 onderskeidelik.

Die eerste verpleegdienste in hierdie gebiede was deur Wit verpleegkundiges van verskillende nasionaliteite verskaf. Sendinghospitale het 'n groot rol gespeel in die opleiding van Swart verpleegkundiges in die voorsiening van gesondheidsdienste aan hul eie mense.

Veral na die Tweede Wêreldoorlog het die opleiding van Swart verpleegkundiges toegeneem en tans is daar Swart matrones van alle kategorieë sowel as gegradueerdes.

Transkei het 'n eie Raad op Verpleging en Bophuthatswana is in die proses. Sodoende het Swart verpleegkundiges bewys dat hul 'n hoë standaard van gesondheidsorg kan handhaaf en kan deelneem aan beleidbepaling op die hoogste vlak.

\section{INTRODUCTION}

$\mathbf{T}$ HE black population of South Africa consists of several different ethnic groups, each with its own historical identity. Seven of these groups have homelands. they are the Xhosa of Ciskei, the Zulu of KwaZulu, the Swazi of Kangwane, the Changana/Tonga of Gazankulu, the Basotho of QwaQwa, the North Sotho of Lebowa, and the Venda of Venda.

The Xhosa of Transkei and the Tswana of Bophuthatswana, two former homelands, became independent during 1976 and 1977 respectively.
All the homelands have their own health and welfare departments. During March 1970 the control of all hospitals in the homelands was transferred to the Department of Bantu Administration and Development. The Department of Health remained responsible for all health services in the homelands, and acted as agent to render the service on behalf of the Department of Bantu Administration and Development.

\section{HISTORICAL BACKGROUND}

The first medical services in the homelands were mostly provided by mission hospitals, and until recently 
the accent was on curative services. The various mission hospitals that were established in the Black States not only provided health services for Black people, but also contributed towards the training of Black nurses, thus involving the Black nurses in providing health services for their own people since the end of the last century. Before that time nursing was provided by White nurses of different nationalities. The British especially made a significant contribution to the development of nursing in South Africa.

In 1856 the first hospital for Black people was established in Kaffraria. Dr. J. P. Fitzgerald, the Superintendent, had a tremendous task in gaining the confidence of the Black people, who were still very suspicious of White medicine. The male dominance in tribal life naturally led to the first hospital attendants being men. They played an important role in leading their own people to accept the White doctor and his medicine. The accent was thus more on hospitalization and the curative aspects of health.

Dr. Fitzgerald and Mrs. E. Parsons did a great deal in the field of nurse-training of Black women during that time. Lovedale Hospital was the first to train Black auxiliary nurses, and issued them with hospital certificates. The first Black professional nurse, Cecilia Makiwane, who was registered in 1908, was also a trainee of Lovedale Hospital. A statue in her honour was erected in the grounds of the Lovedale Hospital in 1977, by the nurses of South Africa.

It was only after the Second World War that the training of Black professional nurses in larger numbers to meet the needs of their people, and to make a significant contribution to nursing in the Black States, gained impetus.

\section{THE HOMELANDS TODAY}

The Department of Health accepted the principle of comprehensive hospital-centred community based health services in the homelands. This includes the integration of the preventive, promotive, curative and rehabilitative aspects of health in the structure of a service. An important new adaptation was the fusion of health and welfare services into a single Department of Health and Welfare. Mission hospitals were nationalized as from 1973.

Hospitals in the homelands are used as centres for comprehensive health services for communities in defined areas. These areas, called health wards, were allocated to each hospital. The area hospital has a superintendent, (the Chief Medical Officer) as well as a matron (the Chief Nursing Officer). They are in charge of the community's health services. Every community is also assisted by nurses, health inspectors and social workers. Where possible each hospital has at least one registered psychiatric nurse and one dietician. Selected hospitals are developed on a regional basis to provide specialised services.

The effectiveness of the service is based on a clear demarcation between the primary, secondary and tertiary service level, and a two-way communication referral system between these levels.

From the outset the Department of Health extended and increased clinics to broaden the services and raise the standard of care. As there are insufficient doctors in many of the remote areas, nurses have to render primary health care under the distant control of the doc- tor. There exists also a shortage of pharmacists, physiotherapists, dieticians, radiographers, laboratory technicians and occupational therapists. Thus the nurse has to step in and provide these services to the best of her ability. She also plays a vital role as health educator in providing health services of a good standard. These nurses working in the community not only render an important health service but they also play a part in community development, by encouraging the community to take part in the planning and implementation of their own health services.

\section{NURSING EDUCATION AS A CONTRIBUTION TO HEALTH SERVICES OF THE BLACK STATES}

In 1927 there were two registered Black female general nurses. In 1957 there were 433, while in 1967 the numbers had increased to 7853 ; and in 1977 there were $16290(3$, p. 28$)$, of whom 10280 were employed in hospitals in the homelands.

There are various factors which have influenced the tremendous increase in the number of registered nurses in the last decade - of which the most important are:

- Increased professional opportunities for registered Black nurses.

- The policy of separate development which has afforded the Black nurses the opportunity of taking over the responsibility for nursing in their own services, especially in the Black States (Mellish p.28).

The first Black matron was appointed in 1958. Today as the result of the different specialization courses in nursing, there are Black matrons of all categories, tutors, community health nurses, paediatric-, intensive care-, operating theatre-, ophthalmic-, and psychiatric nurse specialists.

With the availability of post-registration degree courses of the University of South Africa and at the University of the North, a number of Black nurses are in possession of university degrees in nursing, and some are functioning as lecturers.

In Bophuthatswana 51 nurses are registered for postregistration studies with UNISA. At present there are no post-registration courses available in Bophuthatswana; but the new university which is commencing next year, is planning to offer such courses. $(4$, p.3). This will contribute greatly to the health services of the country, as it will lead to a rise in the standard of education, and thus of nursing care.

The independent country of Transkei has formed its own Nursing Council, and Bophuthatswana is in the process of doing so, thereby showing that they are capable of handling their own nursing affairs and seeing to it that the standard of health services is maintained at a high level. Black women have shown that they can attain high standards of health care, that are comparable to any in the world. They furthermore have proved their ability to take part in policy-making at the highest level.

\section{SOCIAL, CONTRIBUTION}

Many well-educated Black nurses are married to important figures in the homelands and not only do they contribute to the health services in the areas where they work as nurses, but they also play an integral role in the community where they function as housewives. They thus extend a beneficial influence on the community in the attainment of a high standard of health which serves as a foundation for their country. 


\section{PROBLEMS IN THE HEALTH SERVICE OF THE BLACK STATES}

The newly functioning Departments of Health and Welfare are faced with the problem that many of their training hospitals suffer a shortage of tutors and inadequate physical education facilities. It is hoped, however, that the situation will improve in the near future.

Nurses, especially the enrolled nurse and the enrolled nursing assistant will have to be trained for the specific needs of the self-governing states. This will include far greater emphasis on primary care in the rural environment and on community development.

\section{CONCLUSION}

It has taken nearly two centuries to persuade the Black people to accept the White doctor and his medicine, and to overcome their fear of the hospital. The nurses and the community were trained to be hospital-orientated, and the curative aspect of medicine was stressed.

With the advent of the new concept of Comprehen- sive Commmunity Health Care, it is the nurse who has to change her ideas and influence her community to accept, comprehend and live out this concept.

The concept of Comprehensive Care has served to liaise the standards of nursing care and has afforded the nurse a higher status, as her role had to be extended in many areas of health care.

The future is going to demand even greater contributions from nurses, in the light of terrorism and warfare, and the preparation of the community for such experiences.

Community involvement is a concept that has great implications for the improvement of health care in the Black States. The nurse will have to play a vital role in involvement of the community in planning their own health care.

\section{BIBLIOGRA PHY}

1. De Wet, C. N. Community Heslith services, (Bantu, June, 1977, Volume XXIV, no. 5) 2. Matan, T. \& Hattingh, P. S. Black Homelands in South Africa, (The Africa Institute of S.A. 1976).

3. Mellish, J.M. Ethos of Nursing, (Butterworth and Co., 1978)

4. Nursing News, May 1979. 